\title{
Accounting
}

\section{How do merged banks create their intended corporate image? Evidence from Sudan}

\author{
Mohamed Salih Yousif Alia* and Anas Abdulbaset Abbas ${ }^{a}$
}

\begin{tabular}{l} 
a Prince Sattam Bin Abdul Aziz University \\
\hline $\mathbf{C}$ H R O N C L E \\
\hline Article history: \\
Received March 92020 \\
Received in revised format March \\
152020 \\
Accepted May 302020 \\
Available online \\
May 302020 \\
\hline Keywords: \\
Trustworthy behaviors \\
Communication \\
Corporate identity management \\
Intended corporate image \\
Merged banks
\end{tabular}

\section{Introduction}

Transformation in global banking processes has accelerated due to international structural changes in the banking industry and in central banks, and this has triggered mergers among banks in Sudan. In the Last two decades the Sudanese banking sector witnessed three mergers. Mergers in the Sudanese banking sector have attracted very little research attention. This study investigates the impacts of leaders' trustworthy behaviors and how communicating such behaviors contributes to corporate identity management and the formation of the intended corporate image (ICI) in merged banks. ICI is a substantial strategic asset for service corporations, given their leaders' widespread recognition. A corporate image is created not only tangibly but also as a result of the actions and behavior of the company (Villena-Manzanares \& Souto-Pérez, 2016). Researchers have demonstrated that ICI is important for maximizing profit, surviving in the market, retaining customers and developing a positive attitude toward the company's product and services (Brown \& Dacin, 1997; Mazzarol, 1998; Bravo et al., 2009; Sarstedt et al., 2012). In addition, organizations invest in their corporate image (Lamertz et al., 2005) to build a reputation and develop loyalty toward it (Baruch, 2006; Helgesen et al., 2010; Ishaq, 2012). Operationally, ICI refers to the image the banks' leadership expects will be created when the banks merge. Such an image is entrenched in the practiced behaviors and communication.

* Corresponding author. Mobile: +966559684026 Office Phone +966115887456

E-mail address: my.ali@psua.edu.sa (M. S.Y. Ali) 
Trustworthiness is an antecedent of trust, and management considers this a strategic choice (Jones, et al., 2014) that stabilizes organizational commitment to serve other parties' interests (Levi \& Stoker, 2000; Zeffane et al., 2011; Togna, 2014). Banks can improve performance by strategically showing trustworthiness that is related to successful workplace relational strategies. Recent research, through different frameworks, has investigated how managerial trustworthy behaviors impact performance (Bachman \& Inkpen, 2011; Lyman, 2012; Reiche et al., 2014; Hacker et al., 2019). A corporate identity is a set of differentiating characteristics that make a bank unique. The previous studies used two sets of measures for corporate identity because internal and external stakeholders are differently perceived (Van Rekom \& Van Riel, 2000; Lia et al., 2012). Businesses must ensure the same identity orientation for both external and internal stakeholders (Brickson, 2007), choosing from multiple firm identities regarding what is central, distinctive, and enduring about an organization (Pratt and Foreman, 2000). Accordingly, this study analyzes two sub-types of a corporate's identity (organizational identity and organization's identity). Communication is a management function that enables the effective coordination between internal and external stakeholders with the overall purpose of establishing and maintaining favorable reputations and sustainable relationships (Cornelissen, 2011). Communication influences corporate identity, and thus, plays a major role in providing an overview of the leaders' trustworthy behaviors to bank stakeholders. Research suggests that communication is vital for fostering and maintaining relationships (Grönroos, 2004; Finne \& Grönroos, 2009; Dagger et al., 2011). Few quantitative studies have attempted to explore how trustworthy behaviors mechanisms might predicting outcomes especially at merged firms (Dirks and Skarlicki, 2009; Colquitt et al., 2007; McAllister, 1995). During mergers, corporate identity is often subject to change. Similarly, some studies have examined corporate identity in merged firms: Empson (2004) analyzed corporate identity change during mergers, acquisitions, and diversifications, and Brown and Gioia (2002) examined the creation of new divisions within the organization. Studies have also investigated how a bank's corporate identity is created in horizontal mergers when the leaders' trustworthy behaviors are scarce. This study develops a theoretical framework covering nine trustworthy behaviors in one template: competence, integrity, benevolence, reliability, transparency, consistency, delegation, identification, and risk-taking. This framework will describe how and why merged banks that invest in inculcating relationships based on trustworthy behaviors are more likely to develop a new corporate identity and create an ICI through communicating trustworthiness.

The rest of the study is organized as follows. The next section explains the conceptual framework, followed by the literature review. The subsequent sections provide the methodology, data analysis, discussion, implications, limitations, and future research direction, and conclusion.

\section{The conceptual framework}

The framework is based on four arguments such that communicating and aligning trustworthy behaviors with corporate identity allow a bank the opportunity to build favorable perceptions of the ICI, which is tied to corporate identity as a reward for stakeholders. Uncertainty about the future of post-merger stage tends to make some stakeholders hesitate in dealing with the merged bank, and this contributes in eroding their confidence. Moreover, employees' and stakeholders' perceptions of corporate identity are important. Further, we considered that the employees have different look to same leadership when regarding their leaders' trustworthy behaviors. Lastly, corporate communication forms the core of the social interaction process (Grönroos \& Voima, 2013) and enables people with distinct roles to coordinate and control their activities (Tang, 2015). Social exchange theory is used to understand the relationship between perceiving someone as trustworthy and their performance, and for understanding how trustworthiness factors play complementary roles in promoting exchanges that facilitate performance (Dirks and Skarlicki, 2009). Social exchange theory manifests when successful relationships influence the perceptions of employees and stakeholders, allowing them to safeguard their own interpersonal transactions, minimize risks, and build mutual trustworthy behaviors during and after mergers. From this standpoint, we anticipate that trustworthy behaviors significantly influence performance-exchange relationships by influencing performance quality and generating trust commitment.

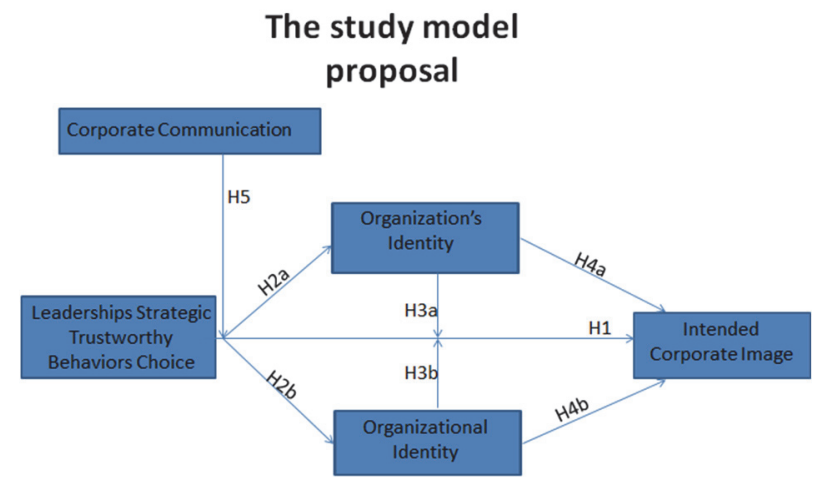

Fig. 1. The proposed method 
Social exchange theory analyzes the impact of trustworthy behaviors and how these behaviors interaction affect performance (Dirks \& Ferrin, 2002; Dirks and Skarlicki, 2009). This study focuses on how perceiving leaders as trustworthy impacts the corporate identity and ICI, by using multiple trustworthy behaviors of leaders as a strategic choice and a foundation for prosperous relationships that may affect performance when corporate communication is effective. Normative and utilitarian approaches by Albert and Whetten (1985) were used to view corporate identity through the belief shared or held by employees and other stakeholders. These approaches help to better understand corporate identity formation. The normative paradigm, as a derivative of the stakeholder theory (Donaldson and Preston, 1995), is specifically oriented toward establishing a relationship between the organization and its stakeholders within an ethical and morally acceptable framework (Mainardes et al., 2011). Through organized behaviors that encourages relationship exchange, leaders can prove their trustworthiness at work. Thus, banks can capitalize on such trustworthy behaviors to achieve their identity goals and their intended image. The proposed model is presented in Fig. 1.

\section{Literature Review}

\subsection{Relationship between trustworthiness, corporate identity, and intended corporate image (ICI)}

Literature on trustworthy behaviors discusses competence, reliability, integrity, benevolence, consistency, identification, risktaking, and delegation. In this study, these nine behaviors are proposed as leaders' trustworthy behaviors. Competence refers to the perception that the target person is trustworthy in terms of having a certain skill set, ability, and competency relevant to managing their demands and expectations effectively (Dirks \& Skarlicki, 2009; Gilstrap \& Collins, 2012; Laura, 2015). Reliability refers to the expectation of consistent and dependable behavior (Hoy and Tschannen-Moran, 1999). Integrity refers to the perception that the person will adhere to sound moral values and act consistently with those values (Dirks and Skarlicki, 2009); this reflects the ethical aspect of trustworthiness and refers to leaders who abides by an accepted set of principles perceived by stakeholders. Benevolence refers to the tendency to help and care for the organization's stakeholders' interests (Edmondson, 1999); in other words, to what extent do leaders work for the wellbeing of stakeholders? Consistency refers to congruency between words and actions, which builds trust across stakeholder groups (Mishra, 1996) rather than letting it diminish. Transparent behavior illustrates that pertinent information is not kept from the key stakeholders. Identification refers to how leaders project themselves to others or explain their actions. Risk-taking refers to taking actions that include risk but also present opportunity in uncertainty. Delegation refers to assigning task-specific authority to juniors who are ready. After a merger, stakeholders expect results from the merged company, and they may have a degree of mistrust toward the new leaders. This may be because they may doubt the new leaders' capabilities in satisfying all stakeholders without surprising them with odd decisions and behaviors. Recently, An Tran et al., (2015) found that the element of trust was most importance in terms of corporate image perception. Thus, strategic trustworthiness refers to behaviors that put leaders in a strong position that allows them to acquire the necessary skills to do their jobs properly. Leaders play a substantial part in communicating and practicing these distinct behaviors in their banks. Thus, the relationship between trustworthy behaviors and ICI is hypothesized as follows:

H1. There is a positive relationship between leaders' strategic trustworthy behaviors choice (LSTBC) and intended corporate image (ICI).

Jones et al. (2014) found that firms could gain performance benefits when they strategically demonstrate trustworthiness. Trust builds feelings of security and safety, and this reduces anxiety (Tams et al., 2018). Banks can foster a favorable image among stakeholders and employees when they are building a favorable corporate identity and demonstrating trustworthy behaviors. Corporate identity and its evolution pertain to the cultural side of the post-merger integration process (De Bernardis, 2012). As mentioned earlier the corporate's identity has sub-types such as organizational identity and organization's identity. Organizational identity refers to the perceptions, feelings, and thoughts of internal stakeholders about their organizations (Hatch \& Schultz, 1997; Alvesson \& Robertson, 2006; Carroll \& Levy, 2008; Russel, 2012; Lim et al., 2015). Operationally, organization's identity refers to the perceptions of external stakeholders of its behaviors and core values. Thus, organization's identity reflects the perceptions of various stakeholders about an organization (Abimbola et al., 2012). A new corporate identity reflects innovation in portraying trustworthiness behaviors, thereby reducing the bank's identity ambiguity. Stakeholders are willing to interact and engage with leaders only to the extent that they perceive the leaders to be trustworthy. Therefore, the following hypotheses are proposed:

$\mathrm{H} 2 \mathrm{a}$ There is a positive relationship between LSTBC and organization's identity.

$\mathrm{H} 2 \mathrm{~b}$ There is a positive relationship between LSTBC and organizational identity.

\subsection{Mediating corporate identity}

Banks can foster a favorable image among stakeholders and employees when they build a favorable identity and demonstrate trustworthy behaviors. The perception of the corporation and its behavior may significantly influence the corporate image (Nguyen \& Leblanc, 2001). Corporate identity is a key to understanding strategic change (Ravasi \& Phillips, 2011), and 
successful major organizational changes found linked to change in it (Corley \& Gioia, 2004; Dutton \& Dukerich, 1991; Gioia, 1998). Organizational leaders play a central role in shaping the corporate identity (Scott and Lane, 2000) and aligning internal and external perceptions of the organization (Hatch and Schultz, 1997). Organization's identity is required to build an external stakeholder group (Corley et al., 2006; Martin et al., 2011), and they will then perceive the organization as legitimate and worthy of their continued support (Ashforth \& Gibbs, 1990). Vierua and Rivard, (2014) examined the effect of differences in organizational identities that emerged during the post-merger project, and they found that the organizational identities-based norms and values are effectively enabling team members and the individual level to collaborate in implementing the information system project context. Members believe that an organizational identity can play a central role in its corporate image projected externally (Fombrun, 1996; Price et al., 2008). Thus, the following hypotheses are proposed:

H3a. An organization's identity mediates the relationship between LSTBC and ICI.

H3b. Organizational identity mediates the relationship between LSTBC and ICI.

New organizations face the challenge of constructing a corporate identity in the face of the need to appear similar to other organizations (Cornelissen et al., 2007; Deephouse, 1999). Post-merger, there is risk of cost of coordination that can arise if the merger was not accurately planned keeping in mind the corporate identity (Porter, 1987). Managing the organization's corporate identity well could eventually enhance the organization's corporate image and improve stakeholders' perceptions of the organization (Kottasz et al., 2008). Corporate identity has the ability to create or destroy coherence between organizational behaviors and stakeholder images (Hatch and Schultz, 2008). Corporate identity enables the firm to distinguish from other companies and define itself meaningfully as a brand. Abimbola et al. (2012) argued that leaders need to establish their corporate identity by addressing questions related to what the organization is and what it seeks to become? The process of organizational identity formation allows the employees to understand their organization better. The stakeholders who form the organization's identity, as external actors have a powerful influence in building identity (Hsu and Hannan, 2005), and therefore, they may occupy a middle ground and be ambivalent (Balmer, 2017). Identity serves as a lens through which the organization is interpreted (Elsbach and Kramer, 1996), which lead to ICI. Thus, the following hypotheses are proposed:

H4a There is a positive relationship between the organization's identity and intended corporate image.

$\mathrm{H} 4 \mathrm{~b}$ There is a positive relationship between organizational identity and intended corporate image.

\subsection{Moderating corporate communication}

Corporate communication offers a framework for effective coordination of all internal and external communication, with the overall purpose of establishing and maintaining coherence among various beliefs between the organization and its stakeholder groups (Cornelissen, 2008; Slabbert, 2016). van Vuuren et al. (2007) found that communication through managers who are seen to represent the organization can influence employees' perception of an organization's values and capabilities. Similarly, employees perceived managers as trustworthy when their communication is accurate and they take time to explain their decisions thoroughly (Whitener et al., (1998). More importantly, a high quality of communication can lead to trust among team members (Dholakia et al., 2004). Communication affects relationship development during mergers by improving positive relationships. Communication researchers identify three factors that affect perceptions of trustworthiness (Whitener et al., 1998): (1) accurate information, (2) explanations for decisions, and (3) openness. Communication strengthens the firm-employee relationship (Herington et al., 2009). Communication keeps stakeholders more aware and satisfied about what the leaders are doing and whether their actions would reduce uncertainty and improve interpersonal relationships. Communication instills confidence in stakeholders that their bank's trustworthy behaviors are the bank's primary behaviors. Thus,

H5a Communication moderates the relationship between LSTBC and organization's identity.

H5b Communication moderates the relationship between LSTBC and organizational identity.

\section{Research Methodology}

The study population consists of banks that underwent horizontal mergers and are listed with the Sudanese central bank (Bank of Sudan). The chosen sample consists of three banks - Nielain Bank Group (NBG), Farmer's Commercial Bank FCB Sudan, and BIue Nile Mashreg Bank (BNMB). The survey was conducted in 2018. The study adopted the questionnaire survey method, a common method used for social research (Neuman, 2006). A statistical consultant helped select the sample type and confirmed the validity of the questionnaire, and seven academicians performed pre-tests from Sudan University of Science and Technology, confirming reliability as higher than 0.85 . Proportionate stratified sampling procedures used with employees coexisted the merging period of banks. A brief personal letter was attached with the questionnaire explaining the purpose of the study, and to assure them that their responses would remain confidential. The questionnaire took less than 10 minutes to complete. The questionnaire was first translated from English to Arabic, and after collecting data, it was again translated into English. Translation was done by two translators, to ensure no loss of meaning. The questionnaire contained five parts. The first part collected information about the respondents' demographic profile (nominal and ordinal scale); the second part is the LSTBC; 
the third part is corporate communication; the fourth part contains corporate identity sub-types (organizational identity and organization's identity); and the fifth part is ICI. All statements were based on a Likert-type scale from (1) strongly disagree to (5) strongly agree. Descriptive statistics and structural equation modeling (SEM) were used to test the proposed research model and hypotheses. Moreover, an analysis was conducted following Anderson and Gerbing's (1998) suggestions, to test for multicollinearity between the latent and observed variables. In addition, principal factor analysis (PFA), exploratory factor analysis (EFA), the Kaiser-Meyer-Olkin (KMO) test of sampling adequacy, Bartlett's sphericity test for validity, common method bias tests, and confirmatory factor analysis (CFA) were performed. CFA was performed to examine whether the theoretical relationship between statements and their hypothesized factors were supported by data and to test the construct reliability and validity (Cunningham, 2010). Further, to examine the internal consistency and reliability of each construct, reliability tests, including Cronbach's $\alpha$ statistics and composite reliability (CR), were used in this work. AMOS 25.0 statistical packages were used to analyze the data collected.

\subsection{Measurements}

The questionnaire was adapted from well-tested existing scales offered by the extant literature, after it was reworded and modified to suit the banking context, except for the questions relating to the organization's identity. The LSTBC was measured using 19 items related to 9 trustworthy behaviors from scales developed and validated by McKnight et al. (2002), Kim et al. (2004), and Robinson et al. (2013). This variable is the independent variable. Corporate communication was measured with four items borrowed from Ndubisi (2007) and Balaji et al. (2016). This variable is the moderating variable. Corporate identity, used as a mediating variable, comprises two primary variables: Corporate identity, used as a mediating variable, comprises two primary variables: organizational identity, consisting of 5 items borrowed from Albert and Whetten (1985), Gioia and Thomas (1996), van Rekom and van Riel (2000) and Brickson (2005). The scales of these items are validated later in He and Baruch (2009) and Balmer (2017). The organization's identity measures were developed by following the suggestions in Churchill (1979) and Gerbing and Anderson (1988) regarding for scale-development procedures. Here seven items were developed. Following the models by (Dowling, 1986; Bloemer et al., 1998), ICI (which is the dependent variable) was measured using five items adapted from validated measures of Nguyen and Leblanc (2001), Balaji et al. (2016), and Hafez (2018). The appendix shows the items of measurement.

\subsection{Test for common method bias}

To prevent or minimize the potential threats of common methods bias (CMB) to occur, a careful questionnaire design based on previous studies was used. In the EFA, items were loaded on five factors. The first factor explained $22.51 \%$ of the variance in the data. Because the items did not load on a single factor, and there was no dominant factor with the majority of the variance, there was no indication of a common method bias (Harman, 1967; Podsakoff \& Organ, 1986; Podsakoff et al., 2003). In addition, comparing a single uncalculated latent method factor with original CFA indicates the absence of CMB in the dataset (see Jones et al., 2014).

\subsection{Sample and data collection}

Proportionate stratified sampling was used to cover three horizontally merged banks in Sudan. Proportionate stratified sampling provides a highly representative sample, low selection bias, and better precision.

\section{Table 1}

Demographic profile of the study respondents

\begin{tabular}{|c|c|c|c|}
\hline & & Frequency & Percent \\
\hline \multirow[t]{3}{*}{ Sex } & Male & 240 & 71.43 \\
\hline & female & 96 & 28.57 \\
\hline & Total & 336 & $100 \%$ \\
\hline \multirow[t]{5}{*}{ Age } & Less than 40 & 83 & 24.70 \\
\hline & 40- 49 & 173 & 51.49 \\
\hline & $50-59$ & 61 & 18.15 \\
\hline & 60 and more & 19 & 5.39 \\
\hline & Total & 336 & $100 \%$ \\
\hline \multirow{4}{*}{ Academic Qualification } & Secondary & 12 & 3.57 \\
\hline & Graduate & 223 & 66.37 \\
\hline & Postgraduate & 101 & 30.06 \\
\hline & Total & 336 & $100 \%$ \\
\hline \multirow{5}{*}{ Years of Experiences } & Less than 10 year & 16 & 4.76 \\
\hline & $10-19$ & 91 & 27.08 \\
\hline & $20-29$ & 201 & 59.83 \\
\hline & More than 30 & 28 & 8.33 \\
\hline & Total & 336 & $100 \%$ \\
\hline \multirow[t]{4}{*}{ Number of respondents } & FCB & 175 & 52 \\
\hline & NBG & 135 & 40 \\
\hline & BNMB & 26 & 8 \\
\hline & Total & 336 & $100 \%$ \\
\hline
\end{tabular}


To create greater cooperation and help the authors met the top management of the surveyed banks and explained to them the academic purpose of the study. After the top management got acquainted with the study has been purposed they directed the human resources department (HRD) to facilitate the task of collecting data and distributing the questionnaires in accordance with authors' guidelines. The sample size was 394, out of a total of 1734 employees. The sample size is calculated with an expected response rate of $80 \%, 5 \%$ margin of error, and $95 \%$ degree of confidence. A total of 336 questionnaires were obtained, with an $85 \%$ response rate. Table 1 shows the demographic profile of respondents. Approximately $71.43 \%$ of the respondents are male and $28.57 \%$ are female. Respondents between 40 and 49 years of age represent $51.49 \%$ of the sample; those less than 40 years represent $24.7 \%$; those between 50 and 59 years represent $18.15 \%$, and those 60 years and above represent $5.39 \%$. Of the sample, $66.37 \%$ of the respondents are graduates, $30.6 \%$ have postgraduate education (postgraduate diploma, master and $\mathrm{PhD})$, and $3.57 \%$ have secondary school education. The majority of the respondents $(59.83 \%)$ have banking experience of 20 29 years, $27.08 \%$ have experience of 10-19 years, $8.33 \%$ have experience of 30 years and more, and $4.76 \%$ have less than 10 years of experience. From all the respondents, those who work with the FCB made up 52\%, followed by NBG respondents $(40 \%)$ and $\mathrm{BNMB}$ respondents $(8 \%)$.

\subsection{Data analysis}

\subsubsection{Exploratory Factor Analysis (EFA)}

EFA was conducted on the questionnaire items using Varimax rotated to assess whether the chosen models could display five constructs. The final test outcomes are shown in Table 2.

Table 2

Study's EFA and Cronbach's alpha

\begin{tabular}{|c|c|c|c|c|c|}
\hline $\begin{array}{c}\text { Cronbach's alpha } \\
\text { Factors }\end{array}$ & $\begin{array}{c}.908 \\
1\end{array}$ & $\begin{array}{c}.858 \\
2\end{array}$ & $\begin{array}{c}.823 \\
3\end{array}$ & $\begin{array}{c}.778 \\
4\end{array}$ & $\begin{array}{c}.707 \\
5\end{array}$ \\
\hline LSTBC1 & .791 & & & & \\
\hline$L S T B C 2$ & .755 & & & & \\
\hline$L S T B C 3$ & .740 & & & & \\
\hline$L S T B C 4$ & .712 & & & & \\
\hline LSTBC5 & .692 & & & & \\
\hline LSTBC6 & .640 & & & & \\
\hline$L S T B C 7$ & 609 & & & & \\
\hline$L S T B C 8$ & .576 & & & & \\
\hline ICII & & .801 & & & \\
\hline ICI2 & & .788 & & & \\
\hline$I C I 3$ & & .761 & & & \\
\hline ICI4 & & .589 & & & \\
\hline ORGLIDI & & & .790 & & \\
\hline ORGLID2 & & & .763 & & \\
\hline ORGLID3 & & & .753 & & \\
\hline ORGLID4 & & & .729 & & \\
\hline COMM1 & & & & .766 & \\
\hline COMM2 & & & & .752 & \\
\hline COMM3 & & & & .616 & \\
\hline ORGID1 & & & & & .868 \\
\hline ORGID2 & & & & & .854 \\
\hline ORGID3 & & & & & .840 \\
\hline Eigen Value & 8.726 & 2.014 & 1.482 & 1.247 & 1.228 \\
\hline Variance Explained & 22.51 & 13.40 & 13.30 & 10.42 & 7.18 \\
\hline Total Variance Explained & & & 66.81 & & \\
\hline KMO & & & .897 & & \\
\hline Bartlett's test & & & 4144.89 & & \\
\hline df & & & 231 & & \\
\hline
\end{tabular}

Note: The Appendix shows the equivalents of these abbreviations.

The Kaiser-Meyer-Olkin (KMO) test for sampling adequacy $(\mathrm{KMO}=0.897$, Bartlett's test of sphericity $=4144.89, \mathrm{p}=0.000)$. These values indicate that our sampling adequacy was acceptable compared with $60 \%$ of the benchmark (Hair et al., 2010), and significant Bartlett's test as recommended by Williams et al., (2012), which implies that the study sample data are appropriate for factor analysis. The average variance extracted (AVE) for each construct above the desirable level of 0.50 (Bagozzi \& Yi, 1991), which shows strong internal consistency and reliability. As a result, 18 non-significant items were dropped when we repeated the process after following Hair et al. (2010). Table 2 also shows the statements of the study's model loaded on five factors with eigenvalues exceeding 1.0 . These five factors explain $72.15 \%$ of variance in the data. Factor 1 is manifested by statements that capture the LSTBC, while factor 2 captures ICI's measure statements and factor 3 captures organizational identity measure statements. Factor 4 captures corporate communication measure statements, and factor 5 captures organization's 
identity measure statements. The Cronbach's alpha coefficients values of all the extracted factors are shown in same table. Cronbach's alpha for the eight-item LSTBC variable was 0.908 , for the four-item ICI variable was 0.858 , for the four-item organizational identity was 0.823 , for the three-item corporate communication and organization's identity variables were 0.778 and 0.707 , respectively, which exceed the suggested threshold of 0.7 (Hair et al., 2010).

\subsubsection{Confirmatory factor analysis (CFA)}

Following Anderson and Gerbing (1988), a two-step approach was adopted, which consisted of examining individual measurement models and the structural model. To check reliability and validity of each measurement model, CFA using AMOS25 was applied. The acceptable model fit is shown in Table 3. Through creating covariance between the items, 3 items are removed from 22 model items, which then showed the model fit. In addition, the following guidelines were outlined by Hair et al. (2010): Chi-square by degree of freedom ( $\left.X^{2} / \mathrm{df}\right)$; Hu and Bentler (1997): Goodness-of-fit Index (GFI); Baumgartrer and Hombur (1996): Adjusted Goodness-of-fit Index (AGFI); Bentler and Bonett (1980), Bentler (1990), and Byrne (1994): comparative fit index (CFI); Byrne (2010): standardized root mean square residual (SRMR); and Browne and Cudeck (1993): root mean square error of approximation (RMSEA), a series of shortened versions of the model because of their robustness, stability, and lack of sensitivity to sample size (Hair et al., 2006). The fit indices revealed that $X^{2} / \mathrm{df}=297.405, \mathrm{df}=88, \mathrm{NFI}=$ $3.380, \mathrm{CFI}=0.910, \mathrm{RMSEA}=0.079, \mathrm{GFI}=0.897$, and model $\mathrm{RMR}=.048$. The above indicators altogether indicated a desirable fit.

Table 3

The study model fit

\begin{tabular}{llll}
\hline Measure & Estimate & Threshold & Model's Interpretation \\
\hline CMIN & 460.365 & - & - \\
DF & 177 & -- & - \\
CMIN/DF & 2.601 & Between 1 and 3 & Excellent \\
CFI & 0.915 & $>0.95$ & Acceptable \\
SRMR & 0.085 & $<0.08$ & Excellent \\
RMSEA & 0.069 & $<0.06$ & Acceptable \\
PClose & 0.000 & $>0.05$ & Acceptable \\
\hline
\end{tabular}

\subsubsection{Validity and Reliability:}

This section reports the results of validity and reliability tests to assess the goodness of measure of the study constructs (Sekaran, 2003). A reliability test checks the internal consistency of measurement items per variable in different settings and conditions (Vitolins et al., 2000). Table 4 shows the composite reliability estimates of all factors were between .761 and .893, suggesting acceptable reliability (Hair et al., 2010; Bagozzi \& Yi, 1988). The construct validity examines the extent to which a scale truly measures a construct of interest, including convergent and discriminant validity (Peter, 1981). Both AVE values and composite reliability are satisfactory, showing the study model's acceptable convergent validity. All the study constructs' AVE values exceed 0.5, confirming adequate discriminant validity of the constructs (Hair et al., 2010). Based on these outcomes, the proposed study measurement model was found to be a valid and reliable model in terms of the observed items' discriminant validity, convergent validity, and internal consistency.

Table 4

Reliability and validity of measurement models

\begin{tabular}{|c|c|c|c|c|c|c|c|c|c|}
\hline & C.R. & AVE & MSV & ASV & 1 & 2 & 3 & 4 & 5 \\
\hline 1- Intended Image & 0.761 & 0.598 & 0.716 & 0.562 & 0.631 & & & & \\
\hline 2- Trustworthy behaviors & 0.834 & 0.507 & 0.729 & 0.555 & 0.735 & 0.712 & & & \\
\hline 3- Organizational Identity & 0.893 & 0.660 & 0.587 & 0.248 & 0.766 & 0.636 & 0.678 & & \\
\hline 4- Communication & 0.781 & 0.791 & 0.716 & 0.315 & 0.846 & 0.739 & 0.696 & 0.753 & \\
\hline 5- Organization's Identity & 0.857 & 0.607 & 0.729 & 0.283 & 0.636 & 0.854 & 0.764 & 0.694 & 0.733 \\
\hline
\end{tabular}

\subsubsection{Structural model and hypotheses testing}

After securing the reliability and validity of individual measurement models, the overall model fit was assessed by the SEM. Table 5 presents the standardized path coefficients and shows that the proposed model fits the data reasonably, according to Bagozzi and Yi, (1991) and Hair et al., (2010).

\section{Direct Effects}

The structural model reveals the same value of model fit shown in Table 3, all the model fit indices for the structural model were not only significant but remain the same as in the measurement model. The low index of R square (i.e., 0.61 and 0.58 ) justifies the underlying theoretical model. Table 5 depicts the results of the hypotheses testing. The paths of all hypothesized 
relationships were significant and supported. As summarized in Table 5, LSTBC was found to have a positive influence on the organization's identity and organizational identity $(\beta=.705, p<.01$ and $\beta=.293, p<.01)$, respectively, which supports $\mathrm{H} 2 \mathrm{a}$ and H2b. Moreover, LSTBC was found to have a positive influence on ICI $(\beta=.296, p<.01)$; H1 was therefore supported in this study. Corporate identity dimensions (organization's identity and organizational identity) were found to have a positive impact on ICI $(\beta=.171, p<.01$ and $\beta=.380, p<.01)$, respectively which lends support for $\mathrm{H} 4 \mathrm{a}$ and $\mathrm{H} 4 \mathrm{~b}$.

Table 5

Regression Weights: (Group number 1 - Default model)

\begin{tabular}{lllrrrrr}
\hline \multicolumn{1}{c}{ Relationships } & & & Estimate & S.E. & C.R. & P & Results \\
\hline Organization's Identity & $\leftarrow$ & LSTBC & .705 & .055 & 12.748 & $* * *$ & Supported \\
Organizational Identity & $\leftarrow$ & LSTBC & .293 & .046 & 6.348 & $* * *$ & Supported \\
ICI & $\leftarrow$ & Organization's identity & .171 & .051 & 3.371 & $* * *$ & Supported \\
ICI & $\leftarrow$ & Organizational identity & .380 & .092 & 4.118 & $* * *$ & Supported \\
ICI & $\leftarrow$ & LSTBC & .296 & .090 & 3.290 & .001 & Supported \\
\hline
\end{tabular}

\section{The mediating effect of corporate identity}

The proposed model assigns LSTBC as an exogenous construct, while corporate identity (organizational identity, organization's identity) and ICI are endogenous constructs. This model is estimated by constraining the direct and indirect effect of LSTBC on ICI to examine the mediating effect of organizational identity and organization's identity. The role of the corporate identity as a mediator was assessed through two hypotheses (H3a and H3b). Preacher and Hayes (2004) and Zhao et al. (2010) suggested that full mediation occurs if (1) an insignificant relationship exists between the independent variable (LSTBC) and dependent variable (ICI) and (2) a significant relationship exists in the indirect path through the mediator variables (organizational and organization's identity). Partial mediation occurs if (1) a significant relationship exists between the independent variable (LSTBC) and dependent variable (ICI) and (2) a significant relationship exists in the indirect path through the mediator (corporate identity variables). Thus, mediation can occur even though the criteria of Baron and Kenny (1986) were not met. For the test of $\mathrm{H} 3 \mathrm{a}$ and $\mathrm{H} 3 \mathrm{~b}$, in the mediation analysis, a linear regression analysis procedure described by Preacher and Hayes (2004) and Zhao et al., (2010) was performed. Hypothesis H3a was not supported based on SEM analysis path coefficient decomposition, as shown in Table 6 . Beta indirect effect estimates $.022, \mathrm{P}=.878$. On the other hand, hypothesis H3b was partially supported based on the SEM analysis, as illustrated in Table 6. The LSTBC had a statistically significant direct impact on ICI and a significant indirect impact on ICI, when organizational identity involved between them. Beta indirect effect estimates $.218, \mathrm{P}=.001$ on ICI. Generally, according to these findings, it can be concluded that organizational identity partially mediates the LSTBC and ICI relationship. Therefore, this partial mediation helps explain the idea that ICI is driven by LSTBC and organizational identity.

\section{Table 6}

Indirect Effects

\begin{tabular}{cccc}
\hline Hypotheses & Indirect Effects & Significance & Result \\
\hline LSTBC $\leftarrow$ Organization's identity $\leftarrow$ ICI & .022 & .878 & No mediation \\
LSTBC $\leftarrow$ Organizational identity $\leftarrow$ ICI & .218 & .001 & partial mediation \\
\hline
\end{tabular}

\section{The moderating effect of corporate communication}

To test the moderating impact of corporate communication on corporate identity (H5a, H5b), the study followed Ping (1995), Baron and Kenny (1986), and Sharma et al. (1981) to moderate structural equation modeling (MSEM), using the three steps described by Cortina et al. (2001). This is because moderated regression analysis limits the investigation to one dependent variable at a time and can lead to loss of statistical power, as reliability decreases (Aiken and West, 1991), biased coefficient estimates (Ping, 1995), and all the variables being latent. Following these three steps, the model fit shown in Table 7. H5a proposed that corporate communication will moderate the positive relationship between LSTBC and organization's identity, such that the relationship will be stronger when corporate communication is higher. The findings showed that the interaction coefficient for corporate communication and LSTBC was insignificant $(\beta=.036, p<.10)$. Thus, the hypothesis H5a was not supported. Additionally, H5b predicted corporate communication will moderate the positive relationship between LSTBC and organizational identity such that the relationship will be stronger when corporate communication is higher. The results from Table 7 show that the interaction coefficient for corporate communication and LSTBC is significant $(\beta=.198, p<.001)$. Thus, hypothesis H5b was supported. Furthermore, to confirm that the moderator type is quasi-moderating, according to the criteria of Sharma et al. (1981), if the coefficients of both the multiplicative interaction term and the moderator variable are significant, the moderator is a quasi-moderator. Thus, the corporate communication variable is a quasi-moderator in the relationship between LSTBC and organizational identity. 
Table 7

Results of study model hierarchical regression analysis

\begin{tabular}{|c|c|c|c|c|c|c|}
\hline Relationships & & & Estimate & S.E. & C.R. & $\mathrm{P}$ \\
\hline Organization's identity & $\leftarrow$ & LSTBC & .705 & .055 & 12.748 & $* * *$ \\
\hline Organizational identity & $\leftarrow$ & LSTBC & .293 & .046 & 6.348 & $* * *$ \\
\hline Organization's identity & $\leftarrow$ & Communication & .215 & .078 & 2.751 & .006 \\
\hline Organizational identity & $\leftarrow$ & Communication & .517 & .093 & 5.529 & $* * *$ \\
\hline Organization's identity & $\leftarrow$ & ZLSTBC X Z Communication & .036 & .052 & .697 & .486 \\
\hline Organizational identity & $\leftarrow$ & ZLTSBC X Z Communication & .198 & .032 & 6.278 & $* * *$ \\
\hline
\end{tabular}

On the other hand, illustrating the nature of the moderator interaction, a simple slope plot analysis is used to see the degree of occurrence at a low level and at a high level of moderation. This simple slope plot analysis provides further support for relationship setting. Fig. 2 shows the interaction and plots that the positive relationship between LSTBC and organizational identity strengthens when corporate communication is high. The relationship is different at low levels of corporate communication compared with high levels of corporate communication because LSTBC will not be the same at different corporate communication levels. This result indicates that merged banks that possess high levels of corporate communication show a positive impact of LSTBC on organizational identity at a high range of LSTBC.

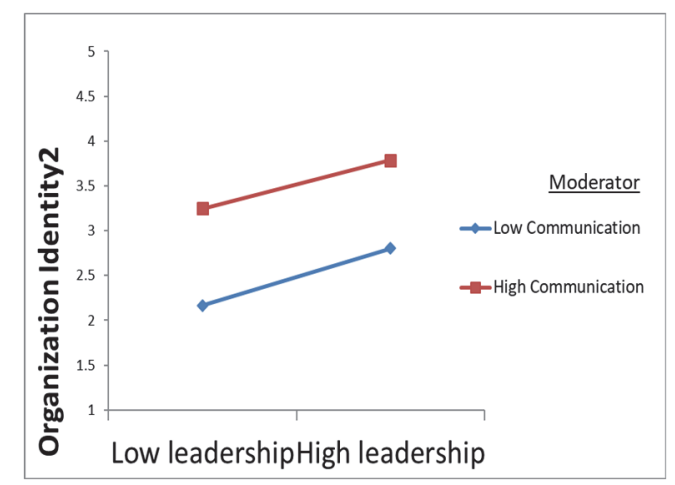

Note: organization identity $2=$ organizational identity

\section{Discussion}

Fig. 2. Interactions between LTWSC and communication on organizational identity

The data from this study show that LSTBC has a positive relationship with corporate identity and ICI. Leaders' trustworthy behaviors set the template for building a bank corporate identity that is distinct from that of other organizations or its own past identity. Trustworthy behaviors play a major role in performance exchange relationships. A firm's trustworthy behaviors fulfill its brand promises and adhering to their essence leads to the formation of the ICI. Leaders' willingness to practice trustworthy behaviors and their capability to do it on a daily basis in banks will determine the bank's ability to interact with stakeholders, maintain key relationships, and realize mutual benefits. In this study, factor analysis deleted identification items such as trustworthy behavior, which matched the previous theoretical and empirical research that found that identification does not play an important role in the trust process (Ellis and Shockley-Zalabak, 2001). These findings in general agreed with the previous empirical studies that supported the relationship between trustworthiness, identity, and image (Ganesan, 1994; Doney and Cannon, 1997; Merrilees \& Fry, 2002; Walsh et al., 2009; An Tran et al., 2015). These findings concur with prior research such as by Debora Riantoputra (2010), who stated that some top managers have the potential to explain and are able to activate their corporate identity concepts; they therefore have the ability to gain performance benefits. Corporate identity dimensions (organization's identity and organizational identity) have a positive relationship with ICI; this finding supports the works of Williams (2008), Cornelissen (2011), Schmeltz (2014), and Arac1, (2019), who found that corporate identity that perceived as important value is central to the building of images, reputations, and legitimacy of companies. Additionally, it is important to ensure that there is consistency between identity and image (Cornelissen, 2008; Argenti, 2007). Corporate identity provides banks with a degree of respect, giving it a competitive advantage. Leaders may need to develop trustworthy behaviors as part of their strategy. In addition, the partial mediating effect of organizational identity between LSTBC and ICI has also been discussed. As leaders practice such behaviors and support stakeholders, the latter perceive these behaviors as the corporate identity, which in turn fosters their intended bank image. This finding agrees with that of Dowling (2001), who found that projection of organizational identities on the corporate website translated into building a corporate image. It also agrees with Dutton and Dukerich (1991) and Gioia and Thomas (1996), who found organizational identity and organizational image to be closely related. It further agrees with van Dick et al. (2018), who found that employees' perceived identities uniquely based on 
effectiveness of leadership behaviors. Finally, communication moderated the relationship between LSTBC and organizational identity. This finding is consistent with previous research that claimed that when managers exchange thoughts, ideas, and behaviors freely with employees, it enhances perceptions of trust (Butler, 1991; Hart et al., 1986; Park et al., 2012). Further, effective communication can remove employees' perception overlaps and their interpretation differences.

\subsection{Limitations and future research}

This study has certain limitations. The study was based on the investigation of the trustworthiness behaviors of leaders in merging banks in Sudan only. For future research, other countries and sectors may also be included. Moreover, this study only used nine instruments for measuring trustworthiness, which is a multi-dimensional instrument. Therefore, future research should increase the number of instruments to test their effects on merged banks. In addition, the study approach was quantitative, and future research could attempt to qualitatively analyze the issue.

\section{Conclusion}

The framework developed by this study has both theoretical and practical significance. It explains why and how trustworthy behaviors contribute to building identity and developing an image. When leaders invest in trustworthy behaviors to improve performance, they are typically asked to open up to stakeholders because doing so is beneficial to the merged business, helping the new entity to quickly establish a corporate identity and intended image through effective communication. Trustworthiness behaviors can be critical factors in generating competitive advantage, but leaders in merged banks must consider and implement them as a strategic choice to benefit from the resulting relationships; this would create a vital corporate identity and intended image. When stakeholders experience trustworthy interactions, they are likely to become more conscious and feel that the leaders could lead positive change. To develop strong employment relations or to maximize positive relationships, merged banks should take insightful perspectives that recognize the importance of trustworthiness for employee retention, stress reduction, and raising morale of employees and other stakeholders' loyalty.

\section{Acknowledgements}

The authors would like to thank the top management, HR departments, and employees of the Sudan three merged banks (BNMB, NBG, and FCB) for facilitating the data collection process, Dr. Emad Aldeen Essa Eshag at College of Business Studies Sudan University of Science and Technology (Khartoum, Sudan), for Statistical Consulting and analysis support, Dr. Abbul Mutalb Mohamed Ali and Dr. Mohammed Bouhmala Assistant Professor at Prince Sattam Bin Abdul Aziz University (Al-aflaj, Saudi Arabia), for translating the questionnaire and my previous Colleagues in college of business studies at Sudan University of Science and Technology, for reviewing and pretesting the study.

\section{References}

Abimbola, T., Trueman, M., Iglesias, O., Abratt, R., \& Kleyn, N. (2012). Corporate identity, corporate branding and corporate reputations. European Journal of Marketing., 46(7/8), 1048-1063.

Aiken, L. S., \& West, S. G. (1991). Multiple regression: Testing and interpreting interactions. Thousand Oaks, CA: Sage.

Albert, S., \& Whetten, D. A. (1985). Organizational identity. Research in Organizational Behavior, 7, 263-295.

Alvesson, M., \& Robertson, M. (2006). The best and the brightest: the construction, significance and effects of elite identities in consulting firms. Organization, 13(3), 195-224.

Anderson, J. C., \& Gerbing, D. W. (1988). Structural equation modeling in practice: A review and recommended two-step approach. Psychological Bulletin, 103(3), 411.

Argenti, P.A. (2007). Corporate Communication. $4^{\text {th }}$ ed., McGraw-Hill, New York, NY.

Arac1, Ö. (2019). Using content analysis to reveal organizational identity orientation Evidence from the newspaper industry. Management Research Review, 42(3), 314-331.

Ashforth, B. E., \& Gibbs, B. W. (1990). The double-edge of organizational legitimation. Organization science, 1(2), $177-194$.

Bachman, R., \& Inkpen, C. (2011) Understanding institutional-based trust building processes in inter-organizational relationships. Organization Studies, 32(2), 281-301.

Bagozzi, R. P., \& Yi, Y. (1988). On the evaluation of structural equation models. Journal of the academy of marketing science, 16(1), 74-94.

Bagozzi, R.P., \& Yi, Y. (1991). Multitrait-multimethod matrices in consumer research. Journal of Consumer Research, 17(4), 426439.

Balmer, J. M. (2017). The corporate identity, total corporate communications, stakeholders' attributed identities, identifications and behaviours continuum. European Journal of Marketing, 51(9/10), 1472-1502.

Baron, R.M., \& Kenny, D.A. (1986). The moderator-mediator variable distinction in social psychological research: conceptual, strategic, and statistical considerations. Journal of Personality and Social Psychology, 51(6), 1173-1182. 
Baruch, Y. (2006). On logos, business cards: the case of UK universities. in Rafaeli, A. and Pratt, M.G. (Eds), Artifacts and Organizations: Beyond Mere Symbolism, Lawrence Erlbaum Associates, Mahwah, NJ, pp. 181-98.

Balaji, M. S., Roy, S. K., \& Wei, K. K. (2016). Does relationship communication matter in B2C service relationships?. Journal of Services Marketing, 30(2), 186-200.

Baumgartrer, H., \& Hombur, C. (1996). Applications of structural equation modeling in marketing and consumer research: A review. International Journal of Research in Marketing, 13(2), 139-161.

Bentler, P. M. (1990). Comparative fit indexes in structural models. Psychological Bulletin, 107(2), 238-246.

Bentler, P. M., \& Bonett, D. G. (1980). Significance tests and goodness-of-fit in the analysis of covariance structures. Psychological Bulletin, 88(3), 588-600.

Bernardis, L. D. (2012). Social dimension in ERP adoption and implementation: The evolution of organizational identity after an M\&A. Journal of Information, Communication and Ethics in Society, 10(3), 156-186.

Bloemer, J., Ruyter, K., \& Peeters, P. (1998). Investigating drivers of bank loyalty: the complex relationship between image, service quality and satisfaction. International Journal of Bank Marketing, 16(7), 276-86.

Byrne, B. M. (1994). Structural equation modeling with EQS and EQS/Windows: Basic concepts, applications, and programming. Sage.

Bravo, R., Montaner, T., \& Pina, J. M. (2009). The role of bank image for customers versus noncustomers. International Journal of Bank Marketing, 27(4), 315-334.

Brickson, S. L. (2005). Organizational identity orientation: Forging a link between organizational identity and organizations' relations with stakeholders. Administrative Science Quarterly, 50(4), 576-609.

Brickson, S. L. (2007). Organizational identity orientation: The genesis of the role of the firm and distinct forms of social value. Academy of Management Review, 32(3), 864-888.

Brown, M., \& Gioia, D.A. (2002). Making things click: distributive leadership in an online division of an offline organization. Leadership Quarterly, 13(4), 397-419.

Brown, T.J. and Dacin, P.A. (1997). The company and the product: corporate associations and consumer product responses. The Journal of Marketing, 61(1), 68-84.

Browne, M. W., \& Cudeck, R. (1993). Alternative Ways of Assessing Model Fit, Testing Structural Equation Models. Sage Publications, California (1993), 136-162.

Butler, J. K., Jr. (1991). Towards understanding and measuring conditions of trust: Evolution of conditions of trust inventory. Journal of Management, 17(3), 643-663.

Byrne, B.M. (2010). Structural Equation Modeling with AMOS: Basic Concepts, Applications and Programming. Taylor and Francis Group, LIC, Philadelphia.

Carroll, B., \& Levy, L. (2008). Defaulting to management: leadership defined by what it is not. Organization. 15(1), 75-96.

Churchill Jr, G. A. (1979). A paradigm for developing better measures of marketing constructs. Journal of Marketing Research, 16(1), 64-73.

Colquitt, J. A., Scott, B. A., \& LePine, J. A. (2007). Trust, trustworthiness, and trust propensity: A meta-analytic test of their unique relationships with risk taking and job performance. Journal of Applied Psychology, 92(4), 909-928.

Corley, K., Harquail, C., Pratt, M., Glynn, M., Fiol, C., \& Hatch, M. (2006). Guiding organizational identity through aged adolescence. Journal of Management Inquiry, 15(2), 85-99.

Corley, K.G., \& Gioia, D.A. (2004). Identity ambiguity and change in the wake of a corporate spin-off. Administrative Science Quarterly, 49(2), 173-208.

Cornelissen, J. (2011). Corporate communication: A guide to theory and practice (3rd ed.). London, UK: Sage.

Cornelissen, J. P., Haslam, S. A., \& Balmer, M. T. (2007). Social identity, organizational identity and corporate identity: Towards an integrated understanding of processes, patternings and products. British Journal of Management, 18(1) Special Issue, S1-S16.

Cornelissen, J.P. (2008). Corporate Communication: A Guide to Theory and Practice, 2nd ed., Sage Publications, London.

Cortina, J. M., Chen, G., \& Dunlap, W. P. (2001). Testing interaction effects in LISREL: Examination and illustration of available procedures. Organizational Research Methods, 4(4), 324-360.

Cunningham, E. (2010), A Practical Guide to Structural Equation Modelling using Amos, 1st ed., Statsline, Melbourne.

Dagger, T.S., David, M.E. and Ng, S. (2011). Do relationship benefits and maintenance drive commitment and loyalty? Journal of Services Marketing, 25(4), 273-281.

Debora Riantoputra, C. (2010). Know thyself: Examining factors that influence the activation of organizational identity concepts in top managers' minds. Group \& Organization Management, 35(1), 8-38.

Deephouse, D. L. (1999). To be different, or be the same? It is a question (and theory) of strategic balance. Strategic Management Journal, 20(2), 147-166.

Dirks, K. T., \& Skarlicki, D. P. (2009). The relationship between being perceived as trustworthy by coworkers and individual performance. Journal of Management, 35(1), 136-157.

DA, L. H. (2015). Building Trusting Relationships in the Medical Practice Team: Thirty Rules to Live By for You and Your Staff. The Journal of medical practice management: MPM, 31(1), 40.

Dholakia, U.M., Bagozzi, R., \& Pearo, L.K. (2004) a social influence model of consumer participation in network- and small-groupbased virtual communities. International Journal of Research in Marketing, 21(3), 241-263.

Donaldson, T., \& Preston, L. E. 1995. The stakeholder theory of the corporation: Concepts, evidence, and implications. Academy of Management Review, 20(1), 65-91. 
Doney, P., \& Cannon, J. (1997). An Examination of the Nature of Trust in Buyer-Seller Relationships. Journal of Marketing 61(2), $35-51$.

Dowling, G. (2001). Creating Corporate Reputations: Identity, Image and Performance. Oxford University Press, London.

Dowling, G.R. (1986). Managing your corporate images. Industrial Marketing Management, 15(2), 109-115.

Dutton, J. E., \&Dukerich, J. M. (1991). Keeping an eye on the mirror: Image and identity in organizations. Academy of Management Journal, 34(3), 517-555.

Edmondson, A. (1999). Psychological safety and learning behavior in work teams. Administrative Science Quarterly, 44(2), 350-383.

Elsbach, K., \& Kramer, R. (1996). Members' responses to organizational identity threats: encountering and countering the business week rankings. Administrative Science Quarterly, 41(3), 442-476.

Ellis, K., \& Shockley-Zalabak, P. (2001). Trust in top management and immediate supervisor: The relationship to satisfaction, perceived organizational effectiveness, and information receiving. Communication Quarterly, 49(4), 382-398.

Empson, L. (2004). Organizational identity change: managerial regulation and member identification in an accounting firm acquisition. Accounting, Organizations \& Society, 29(8), 759-82.

Finne, Å., \& Grönroos, C. (2009). Rethinking marketing communication: from integrated marketing communication to relationship communication. Journal of Marketing Communications, 15(2/3), 179-195.

Fombrun, C.J. (1996). Reputation: Realizing Value from the Corporate Image. Harvard Business Review Press, Boston, MA.

Ganesan, S. (1994). Determinants of long-term orientation in buyer-seller relationships. Journal of Marketing, 58(2), 1-19.

Gioia, D. (1998). "From individual to organizational identity", in Whetten, D. and Godfrey, P. (Eds), Identity in Organizations: Developing Theory through Conversations, Sage, Thousand Oaks, CA, pp.17-31.

Gioia, D. and Thomas, J. (1996). Identity, image and issue interpretation: sense making during strategic change in academia. Administrative Science Quarterly, 41(3), 370-403.

Gilstrap, J. B., \& Collins, B. J. (2012). The importance of being trustworthy: Trust as a mediator of the relationship between leader behaviors and employee job satisfaction. Journal of Leadership \& Organizational Studies, 19(2), 152-163.

Grönroos, C. (2004). The relationship marketing process: communication, interaction, dialogue, value. Journal of Business \& Industrial Marketing, 19(2), 99-113.

Grönroos, C., \& Voima, P. (2013). Critical service logic: making sense of value creation and co-creation. Journal of the Academy of Marketing Science, 41(2), 133-150.

Hacker, J. V., Johnson, M., Saunders, C., \& Thayer, A. L. (2019). Trust in Virtual Teams: A Multidisciplinary Review and Integration. Australasian Journal of Information Systems, 23.

Hafez, Md. (2018). Measuring the impact of corporate social responsibility practices on brand equity in the banking industry in Bangladesh: The mediating effect of corporate image and brand awareness. International Journal of Bank Marketing, 36(5), 806822.

Hair, J. F., Black, W. C., Babin, B. J., \& Anderson, R. E. (2010). Multivariate data analysis (7th ed.). Upper Sadle River, NJ: Pearson Prentice Hall.

Hair, J.F., Black, W.C., Babin, B.J., Anderson, R.E., \& Tatham, R.L. (2006). Multivariate data analysis (6th ed.). Upper Saddle River, NJ: Pearson.

Harman, H. (1967). Modern Factor Analysis. Chicago, IL: University of Chicago Press.

Hart, R. K., Caps, H. R., Cangemi, J. P., \&Caillouet, L. m. (1986). Exploring organizational trust and its multiple dimensions: A case study of General Motors. Organization Development Journal, 4(2), 31-39.

Hatch, M.J., \& Schultz, M. (2008) Taking Brand Initiative: How Companies Can Align Strategy, Culture, and Identity through Corporate Branding. San Francisco, CA: Jossey-Bass.

Hatch, M.J., \& Schultz, M. (1997). Relations between organizational culture, identity and image. European Journal of Marketing, $31(5 / 6), 356-65$.

Helgesen, Ø, IvarHavold, J., \&Nesset, E. (2010). Impacts of store and chain images on the quality-satisfaction-loyalty process in petrol retailing. Journal of Retailing and Consumer Services, 17(2), 109-118.

Herington, C., Johnson, L.W. and Scott, D. (2009). Firm- employee relationship strength - a conceptual model. Journal of Business Research, 62(11), 1096-1107.

He, H., \& Baruch, Y. (2009). Transforming organizational identity under institutional change. Journal of Organizational Change Management, 22(6), 575-599.

Hoy, W. K., \& Tschannen - Moran, M. (1999). Five Faces of Trust: An Empirical Confirmation in Urban Elementary Schools. Journal of School Leadership 9(3), 184-207.

Hsu, G., \& Hannan, M.T. (2005). Identities, genres, and organizational forms. Organization Science, 16(5), 474-490.

Hu, L. T., \& Bentler, P. M. (1997). Cut-off criteria for fit indexes in covariance structure analysis: Conventional criteria versus new alternatives. Structural Equation Modeling: A Multidisciplinary Journal, 6(1), 1-55.

Ishaq, I. M. (2012). Perceived value, service quality, corporate image and customer loyalty: Empirical assessment from Pakistan. Serbian Journal of Management, 7(1), 25-36.

Jones, S. L., Fawcett, S. E., Wallin, C., Fawcett, A. M., \& Brewer, B. L. (2014). Can small firms gain relational advantage? Exploring strategic choice and trustworthiness signals in supply chain relationships. International Journal of Production Research, 52(18), 5451-5466.

Kim, P. H., Ferrin, D. L., Cooper, C. D., \& Dirks, K. T. (2004). Removing the shadow of suspicion: the effects of apology versus denial for repairing competence-versus integrity-based trust violations. Journal of applied psychology, 89(1), 104. 
Kottasz, R., Bennett, R., Savani, S., \& Ali-Choudhury, R. (2008). The role of corporate art in the management of corporate identity. Corporate Communications: An International Journal, 13(3), 235-254.

Lamertz, K., Heugens, P. P., \& Calmet, L. (2005). The configuration of organizational images among firms in the Canadian beer brewing industry. Journal of Management Studies, 42(4), 817-843.

Levi, M., \& Stoker, L. (2000). Political trust and trustworthiness. Annual Review of Political Science, 3(1), $475-507$.

Li, J., Tang, G., \& Chen, Y. (2012). Firms' human resource in information system and sustainable performance: does their organizational identity matter?. The International Journal of Human Resource Management, 23(18), 3838-3855.

Lim, M., Machado, J. C., Iglesias, O., Xie, C., Bagozzi, R. P., \& Meland, K. V. (2015). The impact of reputation and identity congruence on employer brand attractiveness. Marketing Intelligence \& Planning.

Lyman, A. (2012). The Trustworthy Leader: Leveraging the Power of Trust to Transform Your Organization. Vol First edition. San Francisco, CA: Jossey-Bass; 2012.

Tran, M. A., Nguyen, B., Melewar, T. C., \& Bodoh, J. (2015). Exploring the corporate image formation process. Qualitative Market Research: An International Journal, 18(1), 86-114.

Mainardes, E. W., Alves, H., \& Raposo, M. (2011). Stakeholder theory: issues to resolve. Management Decision, 49(2), $226-252$.

Martin, K. D., Johnson, J. L., \& French, J. J. (2011). Institutional pressures and marketing ethics initiatives: the focal role of organizational identity. Journal of the Academy of Marketing Science, 39(4), 574-591.

Mazzarol, T. (1998). Critical success factors for international education marketing. International Journal of Educational Management, 12(4), 163-175.

McAllister, D.J. (1995). Affect- and cognition-based trust as foundations for interpersonal cooperation in organizations. Academy of Management Journal, 38(1), 24-59.

McKnight, D.H., Choudhury, V., \& Kacmar, C., (2002). Developing and validating trust measures for e-commerce: an integrative typology. Information Systems Research. 13(3), 334-359.

Merrilees, B., \& Fry, M. (2002). Corporate branding: a framework for e-retailers. Corporate Reputation Review, 5(2/3), 213-225.

Mishra, A. K. (1996). Organizational responses to crisis. Trust in organizations: Frontiers of theory and research, 261.

Ndubisi, N.O. (2007). Relationship marketing and customer loyalty. Marketing Intelligence \& Planning, 25(1), 98-106.

Neuman, W.L. (2006). Social research methods: Qualitative and quantitative approaches. Boston: Pearson/ A and B.

Nguyen, N., \& Leblanc, G. (2001). Corporate image and corporate reputation in customers' retention decisions in services. Journal of Retailing and Consumer Services, 8(4), 227-36.

Park, J., Lee, J., Lee, H., \& Truex, D. (2012). Exploring the impact of communication effectiveness on service quality, trust and relationship commitment in IT services. International Journal of Information Management, 32(5), 459-468.

Peter, J. P. (1981). Construct validity: A review of basic issues and marketing practices. Journal of Marketing Research, 18(2), 133145.

Ping, R. A., Jr. (1995). A parsimonious estimating technique for interaction and quadratic latent variables. Journal of Marketing Research, 32(3), 336-347.

Podsakoff, P. M., \& Organ, D. W. (1986). Self-Reports in organizational research: Problems and prospects. Journal of Management, 12(4), 531-544.

Podsakoff, P., S. MacKenzie, and J. Lee. (2003). Common Method Biases in Behavioral Research: A Critical Review of the Literature and Recommended Remedies. Journal of Applied Psychology, 88(5), 879-903.

Price, K. N., Corley, K. G., \& Gioia, D. A. (2008). Reconciling scattered images: Managing disparate organizational Expressions and impressions. Journal of Management Inquiry, 17(3), 173-85.

Preacher, K. J., \& Hayes, A. F. (2004). SPSS and SAS procedures for estimating indirect effects in simple mediation models. Behavior Research Methods, Instruments, \& Computers, 36(4), 717-731.

van Rekom, J., \& van Riel, C. B. (2000). Operational measures of organizational identity: A review of existing methods. Corporate Reputation Review, 3(4), 334-350.

Reiche, B. S., Cardona, P., \& Lee, Y. T. (2014). Why do managers engage in trustworthy behavior? A multilevel cross-cultural study in 18 countries. Personnel Psychology, 67(1), 61-98.

Robinson, S. E., Liu, X., Stoutenborough, J. W., \& Vedlitz, A. (2013). Explaining popular trust in the department of homeland security. Journal of Public Administration Research and Theory, 23(3), 713-733.

Sarstedt, M., Wilczynski, P., \& Melewar, T. C. (2012). Measuring reputation in global markets- A comparison of reputation measures' convergent and criterion validities. Journal of World Business, 48(3), 329-339.

Scott, S. G., \& Lane, V. R. (2000). A stakeholder approach to organizational identity. The Academy of Management Review, 25(1), 43-62.

Schmeltz, L. (2014). Identical or just compatible? The utility of corporate identity values in communicating corporate social responsibility. International Journal of Business Communication, 51(3), 234-258.

Sekaran, U. (2003). Research Methods for Business: A Skill Building Approach. Singapore: John Wiley\& Sons, Inc.

Sharma, S., Durand, M.R. \& Gur-Arie, O. (1981). Identification and analysis of moderator variables. Journal of Marketing Research, $18(3), 291-300$.

Slabbert, Y. (2016). A new conceptual framework to strengthen internal corporate image: A stakeholder-inclusive perspective. Communicatio, 42(2), 253-275.

Tams, S., Thatcher, J. B., \& Craig, K. (2018). How and why trust matters in post-adoptive usage: The mediating roles of internal and external self-efficacy. The Journal of Strategic Information Systems, 27(2), 170-190. 
Tang, F. (2015). When communication quality is trustworthy? Transactive memory systems and the mediating role of trust in software development teams. $R \& D$ Management, 45(1), 41-59.

Togna, G. (2014). Does internal communication to generate trust always increase commitment?: A study at Micron Technology. Corporate Communications: An International Journal, 19(1), 64-81.

Van Dick, R., Lemoine, J. E., Steffens, N. K., Kerschreiter, R., Akfirat, S. A., Avanzi, L., ... \& González, R. (2018). Identity leadership going global: Validation of the Identity Leadership Inventory across 20 countries. Journal of Occupational and Organizational Psychology, 91(4), 697-728.

Vieru, D., \& Rivard, S. (2014). Organizational identity challenges in a post-merger context: A case study of an information system implementation project. International Journal of Information Management, 34(3), 381-386.

Vitolins, M. Z., Rand, C. S., Rapp, S. R., Ribisl, P. M., \& Sevick, M. A. (2000). Measuring adherence to behavioral and medical interventions. Controlled clinical trials, 21(5), S188-S194.

van Vuuren, M., de Jong, M. D., \& Seydel, E. R. (2007). Direct and indirect effects of supervisor communication on organizational commitment. Corporate Communications: An International Journal, 12(2), 116-128.

Whitener, E. M., Brodt, S. E., Korsgaard, M. A., \& Werner, J. M. (1998). Managers as initiators of trust: An exchange relationship framework for understanding managerial trustworthy behavior. Academy of management review, 23(3), 513-530.

Williams, B., Brown, T., \& Onsman, A. (2012). Exploratory factor analysis: A five-step guide for novices. Australasian Journal of Paramedicine, 8(3), 1-13.

Williams, L. (2008). The mission statement: A corporate reporting tool with a past, present and future. Journal of Business Communication, 45(2), 94-119.

Walsh, G., Mitchell, V.W., Jackson, P.R., \& Beatty, S.E. (2009). Examining the antecedents and consequences of corporate reputation: a customer perspective. British Journal of Management, 20(2), 187-203.

Zeffane, R., Syed, A.T., \& James, C.R. (2011). Communication, commitment \& trust: exploring the triad. International Journal of Business and Management, 6(6), 77-87.

Zhao, X., J. G. Lynch, \& Q. Chen. (2010). Reconsidering Baron and Kenny: Myths and Truths about Mediation Analysis. Journal of Consumer Research, 37(2), 197-206.

\section{Appendix}

LSTBC1: I believe that most leaders approach their work with professionalism and dedication (Competence).

LSTBC2: In general, my bank's leaders' promises and obligations toward the staff are reliable (Reliability).

LSTBC3: I believe leaders have high integrity that is characterized in their dealings (Integrity).

LSTBC4: This bank's employees believe that leaders care about their wellbeing and do their best to help them (Benevolence).

LSTBC5: The bank leaders create value congruence, merging different trustworthy behaviors (consistency).

LSTBC6: My leaders keep employees informed regularly by establishing transparent communication processes (Transparency).

LSTBC7: Our leaders often seek out opportunities in uncertain situations (Risk-taken).

LSTBC8: Our leaders delegate completely or partially whenever possible (Delegation).

ICI1: This merged bank looks like a good company to work for or to find excellent financial services.

ICI2: This merged bank is a leading firm in the Sudanese banking industry.

ICI3: Overall, the merged bank was evaluated positively in the eyes of the public.

ICI4: I believe that this merged bank outperforms its competitors when it comes to trustworthy behaviors.

ORGLID1: My affiliation to this merged bank makes me feel that its success is my success.

ORGLID2: I feel being a member in this bank helps me define who I am.

ORGLID3: I feel the need to defend my bank when it is criticized.

ORGLID4: I have a sense of pride in my bank's goals and mission.

COMM1: My bank's leaders keep me informed about important issues in the bank.

COMM2: This bank provides sufficient, accurate, and timely information about its trustworthy' strategy and explains its pros.

COMM3: The bank's employees are satisfied when they receive accurate communication from the leaders about the tasks they have been assigned to.

ORGID1: My bank's stakeholders feel that our bank has carved out a significant place for itself in the Sudanese banking industry.

ORGID2: My bank's stakeholders usually talk about the bank on social networks with great enthusiasm.

ORGID3: This bank's mission is to build awareness about financial transactions in the community.

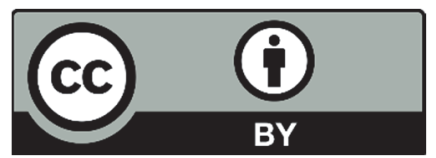

(C) 2020 by the authors; licensee Growing Science, Canada. This is an open access article distributed under the terms and conditions of the Creative Commons Attribution (CC-BY) license (http://creativecommons.org/licenses/by/4.0/). 